\title{
Learning Strategies in Distance Courses: Difference Between Teaching Degree and Extension Courses
}

\author{
Fabiana Maris Versuti ${ }^{1}$ (D), Raíssa Bárbara Nunes Moraes Andrade ${ }^{1,2, *}$ (D), \& Thaís Zerbini $^{1}$ (D) \\ ${ }^{1}$ Universidade Federal de São Paulo, Ribeirão Preto, SP, Brasil \\ ${ }^{2}$ Centro Universitário UNIFAFIBE, Bebedouro, SP, Brasil
}

\begin{abstract}
The learning process includes several specific learning skills. The Learning Strategies, crucial to improve the selection and planning processes of teaching strategies in distance educational actions, is an example. The objective of this study, mainly quantitative in nature, was to compare the use of Learning Strategies by participants enrolled in university extension and teaching degree distance courses. Results found from t-Test point out that Cognitive Strategies, Self-Regulation and Emotion Control are most widely used by participants in the Extension course. It is highlighted the use of Learning Strategies that enable the monitoring and regulation of the organization and the cognitive process by teachers in initial or continuing education must be considered in order to achieve better course planning.
\end{abstract}

KEYWORDS: learning strategies, initial and continuing education, distance education

\section{Estratégias de Aprendizagem em cursos ofertados à distância: Diferença entre cursos de Licenciatura e Extensão}

\begin{abstract}
RESUMO - O processo de aprendizagem envolve, entre outros aspectos, capacidades específicas do aprendiz, tais como as Estratégias de Aprendizagem, as quais são fundamentais para aperfeiçoar a escolha e o planejamento de estratégias de ensino em ações educacionais ofertadas à distância. O objetivo deste estudo, predominantemente quantitativo, consiste em comparar o uso de Estratégias de Aprendizagem de participantes em cursos de Licenciatura e Extensão ofertados à distância. Os participantes são professores em formação inicial e continuada em cursos ofertados à distância por uma Instituição de Ensino Superior de natureza pública. Os resultados encontrados através do Teste $t$ apontam que os participantes do curso de Extensão fazem maior uso de Estratégias Cognitivas, Autorregulatórias e de Controle da Emoção. Destaca-se a necessidade do reconhecimento e uso de Estratégias de Aprendizagem que possibilitem ao professor em formação inicial ou continuada monitorar e regular a organização e o processamento cognitivo dessas informações.
\end{abstract}

PALAVRAS-CHAVE: estratégias de aprendizagem, formação inicial e continuada, educação a distância

Factors related to the characteristics of the target audience of distance education actions (such as Learning Styles, Learning Strategies, and socio-demographic characteristics) are of utmost relevance to the planning of courses in that modality, and are also related to dropout or persistence rates in Distance Education (EAD) (Umekawa \& Zerbini, 2015).

Learning Strategies are procedures (cognitive and behavioral skills) that individuals use during learning activities to ensure the success of all process stages. These are procedures focused exclusively on learning activities. These strategies can be modified by educational actions aimed at increasing learning gain in a specific activity or environment (Warr \& Allan, 1998; Warr \& Downing, 2000; Zerbini \& Abbad, 2008). Martins and Zerbini (2014) state that measuring instruments capable of identifying and assessing the learning strategies employed by students in distance or hybrid courses is of utmost relevance, considering the expansion of this modality.

The analysis and understanding of Learning Strategies could play a valuable role in the improvement of institutional planning of distance actions, as these strategies enable the identification of the individual learning processes used and the teaching procedures most suitable to each agent involved (Santos et al., 2004; Zerbini, 2007; Zerbini \& Abbad, 2010).

*E-mail: raissa.nmoraes@gmail.com

- Submetido: 04/01/2017; Revisado: 05/06/2017; Aceito: 11/03/2018. 
Investigating studies devoted to the variable of Learning Strategies, Umekawa and Zerbini (2015) observed the need for understanding the skills employed by students to study and learn in different educational situations (Costa \& Boruchovitch, 2009; Gomes \& Boruchovitch, 2005; Joly, Cantalice \& Vendramini, 2004; Machado, 2005; Oliveira et al, 2011). Among the studies investigated, the authors found a common concern about the development of meta-cognitive and time-related management Learning Strategies, relevant to the processes of self-regulation of knowledge and time, so typical to Virtual Learning Environments (VLEs).

As Beluce and Oliveira (2012) put it, the scientific productions oriented towards the analysis of Learning Strategies in context of online education is reporting satisfactory advances. However, these advances are not enough considering the importance of the issue in the context of onsite and distance education. There is an urge for the development of studies not limited to the aforementioned aspects, but that could contribute to the study of this matter.

Todorov, Moreira and Martone (2009) discuss the possibilities for students to set their own pace of learning on the course engaging on teaching proposals that adopt the Personalized System of Instruction (PSI) and EAD. This study clearly shows the advantages of this practice to disseminate and democratize quality education, based on empiric evidence of its efficacy.

The findings of Martins' and Zerbini's (2014) study point out the relationship between Learning Strategies and many other variables such as motivation to study, acquisition and retention of content, self-confidence, and even individual variables (age, gender, years of study). The Learning Strategies influence many aspects of the teaching process. However, it is observed the shortage of studies investigate the relationship between Learning Strategies to school Dropout. Umekawa and Zerbini (2015) have already discussed the urgency for investigating this issue. Other studies emphasize other variables such as technical aspects of the interface between students and the electronic environment of the course; instructional procedures of the course; usefulness and applicability of the course; tutor's performance; student's study environment, among other variables crucial for a comprehensive analysis of the phenomenon of dropout in distance courses. However these are not comprised by the objectives of this manuscript (Zerbini \& Abbad, 2005, 2007; Varanda; Zerbini \& Abbad, 2010).
In this context, the expansion of several proposals for teachers' training, which are centered on the development of different digital media increase the access, reach and socialization of information. These facts have facilitated the institution of a new learning culture (Pozo, 2004; Livingstone, 2010). Learning becomes an increasingly present and broad need throughout the lives of individuals, which is translated into proposals of initial and continuing education based on the new information and communication technologies (ICT). However, researchers like Pozo (2004), Kiliç-Çakmak (2010) and Livingstone (2011) emphasize that access to such a multiplicity of information, advocated by the so-called knowledge/learning society (Pozo, 2004), does not effectively ensure the appropriation of knowledge by the individual.

Taking the new ICTs into consideration in the planning and development of teaching proposals allows the access and propagation of information as ways of communicative action, allowing in turn, the changes of behaviors and Learning strategies (Kenski, 2003).

In this sense, Pozo (2004) emphasizes that the strategic adoption of information to build new knowledge urges for specific skills of the learner. In order to do that, the individual should be able of identifying, selecting, interpreting, analyzing and summarizing information, both in strictly onsite teaching conditions as well as in situations facilitated by digital technologies in online or distance context (Livingstone, 2011). Therefore, the teacher acting as a knowledge disseminator should also act as knowledge organizer, defining what and how to teach (Pimenta \& Anastasiou, 2005), while also enabling in those learning environments a critical space to the use of communication technologies.

According to Martins and Zerbini (2014) investigations devoted to the identification of which Learning strategies are more responsive to each distance course could provide relevant information to expand the learning outcomes, and could be taught prior to the distance courses. This increases the importance of studies aimed at the knowledge and development of Learning strategies that could ensure effectiveness to training courses in the scope of initial and continuing education offered in the distance modality, which take the new ICTs as tools to maximize learning.

Therefore, the objective of this study is to compare the use of Learning strategies among participants of the Teaching Degree and Extension courses. Participants are teachers in initial and continuing education, taking distance courses delivered by a public Higher Education Institution.

\section{METHOD}

\section{Target Organization}

The initial proposal of working in the scope of this public University - responsible for delivering the "Sciences
Teaching Degree" program, came from a professional member of the teaching body of the department that houses this teaching degree program, and who also participated in the proposal of the Extension course object of this investigation. 
Then, it was asked to the competent administrative body the permission to collect and use data from referred courses. The required methodological and ethical actions started when the request was accepted. The present study is supported by Resolution no. 196/96 and by the supplements issued by the Brazilian Health Council. All participants signed the Free and Informed Consent Form (FICF).

\section{Target Courses}

The "Sciences Teaching Degree" course, of hybrid modality, started being delivered to meet a demand of specialization of the stages of Basic Education and High School in Sao Paulo. The course is oriented towards the training of individuals that wish to become able the practice of teaching in Basic Education.

The course aims at the development of skills in teachers acting in the field of Sciences in stage II of Grade School. Such preparation implies in the understanding of the Nature Sciences in a broad and integrated way, as well as taking a stance as critical and thoughtful academic capable of driving and encouraging students to the significant learning of sciences. The course lasts 48 months and is divided in 8 modules. Training activities are developed during the modules defined, one every semester. The hybrid modality mixes the onsite and distance modalities, delivering online activities and onsite meetings. The activities planned - webbased activities, reading and onsite meetings - sum up a total of 2,835 hours, as follows:

- 405 onsite hours devoted to the Practices as a Curriculum Component;

- 403 hours of Supervised Curriculum Internship;

- 210 hours devoted to the Academic-ScientificCultural Activities;

- $\quad 1,800$ hours of activities related to the Curriculum Contents of Scientific-Cultural Nature, of which 1,470 hours are developed remotely.

According to the program website 360 annual places are made available every year, distributed along the seven poles. The pole of Ribeirao Preto offers approximately 205 places, considering the four years of the program. No information about Dropout was made available. Therefore, we cannot accurately state the number of students enrolled in the program.

Reaffirming the hybrid modality, it is required at least 10 hours a week ( 2 hours a day) to perform the online tasks. Onsite classes are delivered on Saturdays (8:00 to 12:00 and 13:30 to $17: 30$ ) and approach topics/subjects previously defined in the academic calendar. During onsite classes educators and teachers can adopt different methodological strategies considering the classes and contents to be worked, such as: introduction of new topic during the onsite class that precedes the study of that topic, or review and summary of the object of interest after the week of online studies.
Another course analyzed by this study was the "Technologies and practices in sciences education" extension course, delivered by researchers of a Research Group in Scientific Education belonging to the same public University, in partnership with the Google Educators Group (GEG). A hybrid extension course named "ICTs and Sciences" was offered. The course lasted 30 hours and had as target-audience the teachers of Basic Education (Primary Teaching), Sciences (Biology, Chemistry and Physics) teachers of public and private schools in Ribeirao Preto and surroundings, holding university degree in Sciences (Biology, Chemistry and Physics) willing to expand their knowledge about Scientific Education and its links with the use of ICTs.

The Extension course was divided into 04 units, each one lasting 01 week. Following were the topics:

- Unit 01: History of Sciences and Technology: Life, society and school environment.

- Unit 02: Socio-scientific issues in Science education and the internet.

- Unit 03: Sciences curriculum and Learning objects: practices, tools and strategies.

- Unit 04: Environmental education and technological resources in the classroom.

The activities proposed to the Units consisted of $90 \%$ of online activities and $10 \%$ of onsite activities, that took place on dates and times previously scheduled with the participating teachers.

It becomes clear, in the description of these courses, that they differ in some different aspects, like duration (48 months / 30 hours), objectives (initial teachers training / continuing education) and target audience (individuals willing to be skilled to teach in Basic Education / teachers with university degree and active willing to expand their knowledge).

\section{Population and Sample}

Table 1 shows a summary of the main characteristics of the sample in this study. The target courses can be briefly compared based on this table.

The sample consisted of 135 respondents for the Sciences Teaching Degree program. If we consider the total of 205 places, the return rate was $65.8 \%$. This rate can be considered optimal, especially in the context of remote data collection (Zerbini, 2007). Participated on the survey students of all the program modules.

Respondents' data show that most students are female $(57.8 \%)$, married (48.9\%) and with children (58.5\%). Most of the participants were aged between 40 and 49 years $(0.4 \%)$, with mean age of 38 years $(\mathrm{SD}=10.16)$. The majority of the students had a incomplete higher education level (38.5\%). Among the professions mentioned by participants, teacher was the most frequent (34.8\%). Finally, most of the respondents said to have previous experience in the use of internet $(94.8 \%)$. 
The sample of the Extension course consisted of 37 teachers enrolled in the course and teaching in basic education (Primary Teaching), Sciences (Biology, Chemistry and Physics) teachers in public and private schools in Ribeirao Preto and surroundings, with university degree in Sciences (Biology, Chemistry and Physics). Ages among participants ranged from 28 to 51 years old, with mean age of 33 years old. Most teachers had previous experience in using the internet.

\section{Measure Instruments}

Table 2 shows a summary of the data of the instrument administered in this study, after undergoing explanatory analyses to check its evidence of validity.

The socio-demographic questionnaire was designed to this study and consists of questions about age, sex, marital status, education, profession, household composition and previous use of the internet. The Learning Strategies instrument was proposed by Martins and Zerbini (2014) and derived from the scale of Zerbini et al. (2005). The authors adjusted this instrument in order to fit it to the educational scenarios of distance higher education. Table 2 shows that reliability rates ranged from 0.77 to 9.90 , supporting the internal consistency of the scale. The factor loadings, in turn, ranged from 0.33 to 0.76 , indicating that the scale is valid and comprises representative items of the factor.

\section{Data Collection Procedure}

All data were remotely collected on the Internet, using a free applicative that allowed publishing the questionnaires online through a link provided to participants. Responses were recorded on online software in spreadsheet format, and further imported to the data analysis software. Access to these data was restricted to the researcher in charge and, therefore, data were not public domain.

\section{Data Analysis Procedure}

To comply with the quantitative outline design, data were analyzed through the t-Test calculation, which defined the difference between the mean responses of participants from both courses, comparing them in each factor of the Learning Strategies instrument. To that, missing cases, univariate and multivariate outliers, multicollinearity, singularity and linearity were observed. Missing data were handled using the pairwise method, as no variable presented more than $5 \%$ of missing cases. To identify univariate outliers, all variables were conversed in $\mathrm{Z}$ scores and all responses with standardized scores equal to or higher than $3.29(\mathrm{p}<0.001$, two-tailed) were excluded. The multivariate outliers were identified based on the Mahalanobis distance $(\alpha=0,001)$ and further excluded.

The mean differences test ( $t$-Test) aimed at verifying if the students of the Sciences Teaching Degree program used the Learning Strategies with a different frequency from the Extension course students. Moreover, it allowed verifying which Learning Strategies are more commonly used in one or other course. In order for that to be possible, the Pasquali's (2004) criterion of groups equality was followed. In other words, the number of participants from the Sciences Teaching Degress program should be the same as that for the Extension course. Then, two groups of 12 participants remained. It is worth mentioning that the Teaching Degree program sampling was randomly selected.

Table 1

Summary of the characteristics of this study's sample

\begin{tabular}{lcc}
\hline Course & Sciences Teaching Degree & $\begin{array}{c}\text { Technologies and practices } \\
\text { in sciences education }\end{array}$ \\
\hline Participants & 135 & 37 \\
Mean age & 38 years & 33 years \\
Experience in using the internet & Yes & Yes \\
Prevailing profession & Teacher & Basic Education teacher \\
\hline
\end{tabular}

Table 2

Instrument used in the study after statistic validation

\begin{tabular}{lccccc}
\hline \multirow{2}{*}{ Instrument } & Scales Obtained & No. of items & Alpha & \multicolumn{2}{c}{ Factor loadings } \\
\hline Learning strategies & $\begin{array}{c}\text { Cognitive strategies } \\
\text { Emotion control }\end{array}$ & 15 & 0,90 & 0,33 & Maximum \\
\hline $\begin{array}{c}\text { Self-regulatory } \\
\text { strategies }\end{array}$ & 4 & 0,77 & 0,46 & 0,72 \\
$\begin{array}{c}\text { Search for } \\
\text { Interpersonal } \\
\text { Assistance }\end{array}$ & 3 & 0,86 & -050 & $-0,69$ \\
\hline
\end{tabular}

Source: Martins and Zerbini (2014). 


\section{RESULTS}

To answer the question of this study, the factorial scores of the Learning Strategies instrument and its items were transformed into criterion variables to the analysis model. The students courses were the variables inserted in separate. Therefore, some Learning Strategies used in different ways in both target courses could be identified.

As the Science Teaching Degree sample was bigger and allowed more random samples, three samples were taken from this course and analyzed in separate, with the Extension course. Tables 3 and 4 show a summary of the results found to the factorial scores of Learning Strategies and to the items of that instrument, respectively.

The result of the means difference test ( $t$-Test), considering $\mathrm{p}<0.05$, presented in Table 3 , indicated that students of the Extension courses use the Cognitive Strategies more intensively than students of the Science Teaching Degree program. The students of the Extension course presented mean equal to $8.32(\mathrm{SD}=1.01)$, while the group of students of the Science Teaching Degree program presented mean of $6.98(\mathrm{SD}=1.50)$ to a $t$-Test value of 2.46 $(\mathrm{gl}=17.5 ; \mathrm{p}=0.024)$. The Extension student also uses more frequently the Emotion Control than the student from the Teaching Degree course. The first group presented mean of $9.04(\mathrm{SD}=1.22)$, while the second group presented mean of $6.20(\mathrm{SD}=1.16)$ to a $t$-Test value equal to $5.44(\mathrm{gl}=19$; $\mathrm{p}=0.000$ ). Finally, the group of students of the Extension course uses more intensively Self-regulating Strategies than the students of the Teaching Degree course. The group of students of the Extension course presented mean of 8.32 $(\mathrm{SD}=1.01)$, while the mean for the group of students of the Teaching Degree course was $6.98(\mathrm{SD}=1.50)$ to a $t$-Test of $3.24(\mathrm{gl}=16 ; \mathrm{p}=0.005)$.

These results are confirmed in the individual analyses of the mean responses to each item of the Learning Strategies instrument. Table 4 shows the summary of findings when items are analyzed individually:

Table 3

T test of differences of means to the Strategic Learning Factors according to the course

\begin{tabular}{|c|c|c|c|c|c|}
\hline Course & Mean & Standard Deviation & $t$ & $g l$ & $P * *$ \\
\hline \multicolumn{6}{|c|}{ Mean Learning Strategies - Cognitive Strategies (Factor1Strategy) } \\
\hline $\begin{array}{l}\text { Sciences Teaching } \\
\text { Degree }\end{array}$ & 6,98 & 1,50 & 2,46 & 17,5 & 0,024 \\
\hline Extension & 8,32 & 1,01 & & & \\
\hline \multicolumn{6}{|c|}{ Mean Learning Strategies - Emotion Control (Factor2Strategy) } \\
\hline $\begin{array}{l}\text { Sciences Teaching } \\
\text { Degree }\end{array}$ & 6,20 & 1,16 & 5,44 & 19 & 0,000 \\
\hline Extension & 9,04 & 1,22 & & & \\
\hline \multicolumn{6}{|c|}{ Mean Learning Strategies - Self-regulatory Strategies (Factor3Strategy) } \\
\hline $\begin{array}{l}\text { Sciences Teaching } \\
\text { Degree }\end{array}$ & 6,98 & 1,50 & 3,24 & 16 & 0,005 \\
\hline Extension & 8,32 & 1,01 & & & \\
\hline
\end{tabular}

*Sciences Teaching Degree N=12; Extension N=12

$* *$ Considering $\mathrm{p}<0.05$

Table 4

Summary of the t Test of differences of means to the items of the Learning Strategies instrument

\begin{tabular}{ll}
\hline Variable & \multicolumn{1}{c}{ Result } \\
\hline The Extension course student... & 1. Kept calm when facing difficulties. \\
2. When feeling anxious, repeated to them that everything would be fine by the end of the course. \\
4. Kept calm in face of the possibility of underperforming. \\
5. Reviewed the subject to check to which extent they mastered the content. \\
6. Tried to better understand the contents when they studied these on the course hand-out. \\
7. Tried to understand the content when applying it to real life instead of spending time reading or asking \\
help to someone. \\
8. Tried to develop a global idea about how the course contents are related.
\end{tabular}


It was noticed that the Extension course students achieved higher means to 8 of the 29 items of the Learning Strategies questionnaire. Of these eight, four belong to Emotion Control (1. I kept calm when I faced difficulties; 2. When I felt anxious, I repeated to myself that everything would be fine by the end of the course; 3 . I kept calm in face of the possibility of underperforming; 4. I kept calm in face of my errors when performing the course activities); two belong to Self-regulatory Strategies (8. I reviewed the subject course to check to which extent I mastered the content; 11. I tried to understand better the contents when I studied them on the course hand-out); and, two belong to Cognitive Strategies (17. I tried to understand the content when I applied it to real life instead of spending time reading or asking help to someone; 26. I tried to develop a global idea about how the course content are related).

\section{DISCUSSION OF RESULTS}

The results achieved in this research were based on the data analysis through the $t$-Test, with two distance courses serving as sample. The study indicated significant differences in the use of some Learning Strategies in these different contexts. The group that used these strategies more intensively was the Extension course sample. It was observed, however, that this education modality demanded more intensive use of Learning Strategies from the students to achieve the course objectives.

The cognitive, self-regulatory and emotion control strategies were the most used. The first factor (Cognitive Strategies) studied by Martins and Zerbini (2014) has 12 items derived from the cognitive strategies of repetition, organization and elaboration (active thinking), two items derived from strategies of search for support in teaching material and one of practical application, both behavioral strategies according to Warr and Allan (1998). In this study the authors suggest that cognitive strategies and some behavioral strategies clustered in the same factor. The second factor (Self-regulatory Strategies) is studied by Martins and Zerbini (2014) as a factor with items of strategies of monitoring of understanding, control of motivation, and two items of search of support in teaching material. Finally, the authors state that the Emotion Control factor has items related to strategies that evidence the control of anxiety and prevention of dispersion of concentration caused by feelings of anxiety by the time of studying, according to Warr and Allan (1998).

Therefore, this study pointed out that Extension studies make use of all of the aforementioned Strategies. That means to say that the teachers in continuing education perceive the need of repeating, organizing and elaborating the content learned in the course; of seeking help in teaching material; of recognizing the practical application of what is studied; of consistently monitoring what is being learned; of controlling their motivation during the course, and also controlling their anxiety; and, preventing dispersion by the time of studying.
This context raises the importance of the recognition and use of Learning Strategies that enable the teachers in training, regardless if in initial or continuing education, to monitor and rule the organization and cognitive processing of this information. As observed, teachers exposed to the Extension course have been using the Learning strategies, notably the cognitive strategies, to cope with situations of study. As regards this situation, it is worthy mentioning the urgency of ensuring training spaces to teachers, that make them able to understand and use cognitive and meta-cognitive strategies for their learning, since learning about those strategies is the first requirement to teach students to use them.

In line with Todorov, Moreira and Martone (2009) the results presented and discussed regarding the development of two courses point out the importance of counting on training conditions that give value to the student-centered learning processes. That valuation transfers to the student the role of main player, breaking up with traditional educational paradigms, emphasizing, among others, the student's learning strategies that effectively contribute to the academic success.

This study has also discussed the need for investing in the identification of and training on specific Learning Strategies supportive to the use, understanding and handling of information mediated by the digital / online media. It is expected that these discussions foster new studies, overcoming the limitations posed herein and expanding knowledge related to the topic in investigation.

The study contemplated main objective proposed, i.e., to compare the use of Learning Strategies among students of distance Teaching Degree and Extension courses delivered by a public Higher Education Institution. Finally, it confirms previous study (Martins \& Zerbini, 2014) when it shows that students from different distance courses present different learning strategies, contributing to the design and improvement of educational activities (Zerbini \& Abbad, 2010). 


\section{REFERENCES}

Beluce, A. C., \& Oliveira, K. L. (2012). Ambientes virtuais de aprendizagem: Das estratégias de ensino às Estratégias de Aprendizagem. In $I X A N P E D S U L$ (pp. 1-14).

Costa, E. R., \& Boruchovitch, E. (2009). As Estratégias de Aprendizagem e a produção de textos narrativos. Psicologia: Reflexão e Crítica, 22(2), 173-180.

Gomes, M. A. M., \& Boruchovitch, E. (2005). Desempenho no jogo, Estratégias de Aprendizagem e compreensão na leitura. Psicologia Teoria e Pesquisa, 21(3), 319-326.

Joly, M. C. R. A., Cantalice, L. M., \& Vendramini, C. M. M. (2004). Evidências de validade de uma escala de estratégias de leitura para universitários. Interação em Psicologia, 8, 261-270.

Kenski, V. M. (2003) Tecnologias e ensino presencial e a distância. Papirus Editora.

Kiliç-Çakmak, E. (2010). Learning strategies and motivational factors predicting information literacy self-efficacy of e-learners. Australasian Journal of Educational Technology, 26(2), 192-208

Livingstone, S. (2011). Internet literacy: A negociação dos jovens com as novas oportunidades on-line. MATRIZes, 4(2), 11-42.

Machado, O. A. (2005). Evasão de alunos de cursos superiores: Fatores motivacionais e de contexto. (Master's thesis). Universidade Estadual de Londrina, Londrina, PR, Brasil.

Martins, L. B., \& Zerbini, T. (2014) Escala de estratégias de aprendizagem: Evidências de validade em contexto universitário híbrido. Psico-USF (Impresso), 19, 317-328.

Oliveira, K. L., Boruchovitch, E., \& Santos, A. A. A. (2011). Estratégias de Aprendizagem no ensino fundamental: Análise por gênero, série escolar e idade. Psico, 42(1), 98-105.

Pimenta, S. G., \& Anastasiou, L. G. (2005). Docência no ensino superior ( $2^{\mathrm{a}}$ ed).São Paulo: Cortez.

Pozo, J. I. (2004). A sociedade da aprendizagem e o desafio de converter informação em conhecimento. Pátio: Revista Pedagógica, (31), 8-11.

Santos, A. A. A., Boruchovitch, E., Primi, R., Zenorini, R. P. C., \& Bueno, J. M. H (2004). Escala de avaliação de Estratégias de Aprendizagem para universitários (EAP-U): Aplicação do Modelo de Rasch de créditos parciais. Braga-PT: Psicologia: Teoria, Investigação e Prática, 9(2), 227-242.

Todorov, J. C., Moreira, M. B., \& Martone, R. C. (2009). Sistema personalizado de ensino, educação à distância e aprendizagem centrada no aluno. Psicologia: Teoria e Pesquisa, 25(3), 289-296. https://dx.doi.org/10.1590/S010237722009000300002.

Umekawa, E. E. R. (2014). Preditores de fatores relacionados à evasão e à persistência discente em ações educacionais a distância (Master's thesis). Faculdade de Filosofia, Ciências e Letras de Ribeirão Preto, Universidade de São Paulo, Ribeirão Preto, SP, Brasil.

Umekawa, E. E. R., \& Zerbini, T. (2015). Evasão e persistência em ações educacionais a distância: Análise do perfil discente. Revista Psicologia Organizações e Trabalho, 15(2), 188-200. http://dx.doi.org/10.17652/rpot/2015.2.517

Varanda, R. C., Zerbini, T., \& Abbad, G. (2010). Construção e validação da escala de reações à interface gráfica para cursos de educação a distância. Psicologia: Teoria e Pesquisa, 26(2), 371380. https://dx.doi.org/10.1590/S0102-37722010000200019.

Warr, P., \& Allan, C. (1998). Learning strategies and occupational training. International Review of Industrial and Organizational Psychology, 13, 83-121.

Warr, P., \& Downing, J. (2000). Learning strategies, learning anxiety and knowledge acquisition. British Journal Psychology, 91, 311-333.

Zerbini, T., \& Abbad, G. (2005). Impacto de treinamento no trabalho via internet. Revista de Administração de Empresas Eletrônica, 4. Retrieved from http://www.rae.com.br/ eletronica/index.cfm.

Zerbini, T. (2007). Avaliação da transferência de treinamento em curso a distância (Doctoral dissertation). Instituto de Psicologia, Universidade de Brasília, Brasília, DF, Brasil.

Zerbini, T., \& Abbad, G. (2008). Estratégias de aprendizagem em curso a distância: Validação de uma escala. Psico-USF, 13(2), 177-187.

Zerbini, T., \& Abbad, G. (2010). Aprendizagem induzida pela instrução em contexto de organizações e trabalho: Uma análise crítica da literatura. Cadernos de Psicologia Social do Trabalho, 13(2), 177-193.

Zerbini, T., Carvalho, R. S., \& Abbad, G. (2005). Treinamento a distância via internet: Construção e validação de escala de Estratégias de Aprendizagem [CD-Rom]. In Associação Nacional dos Programas de Pós-Graduação em Administração (Org.), Anais do XXIX ENANPAD. Brasília: ANPAD. 